\title{
Polish Feature Film after 1989
}

\author{
By Tadeusz Miczka
}

Spring 2008 Issue of KINEMA

\section{CINEMA IN THE LABYRINTH OF FREEDOM: POLISH FEATURE FILM AFTER 1989}

\author{
"Freedom does not exist. We should aim towards it but the hope that we will be free is ridiculous." \\ Krzysztof Kieślowski ${ }^{1}$
}

This essay is the continuation of my previous deliberations on the evolution of the Polish feature film during socialist realism, which summarized its output and pondered its future after the victory of the Solidarity movement. In the paper "Cinema Under Political Pressure..." (1993), I wrote inter alia: "Those serving the Tenth Muse did not notice that martial law was over; they failed to record on film the takeover of the government by the political opposition in Poland. [...] In the new political situation, the society has been trying to create a true democratic order; most of the filmmakers' strategies appeared to be useless. Incipit vita nova! Will the filmmakers know how to use the freedom of speech now? It is still too early to answer this question clearly, but undoubtedly there are several dangers which they face." ${ }^{2}$ Since then, a dozen years have passed and over four hundred new feature films have appeared on Polish cinema screens, it is now possible to write a sequel to these reflections.

First of all it should be noted that a main feature of Polish cinema has always been its reluctance towards genre purity and display of the filmmaker's individuality. That is what I addressed in my earlier article by pointing out the "authorial strategies." It is still possible to do it right now - by treating the authorial strategy as a research construct to be understood quite widely: both as the "sphere of the director" or the subjective choice of "authorial role,"3 a kind of social strategy or social contract. ${ }^{4}$ Closest to my approach is Tadeusz Lubelski who claims: "[...] The practical application of authorial strategies must be related to the range of social roles functioning in the culture of a given country and time. They are the result of the concord of these roles with the possibilities which the cinema offers to the filmmaker: the technological, economic, political and expressive possibilities." ${ }^{5}$ In accordance with this author, I can express my research aim: "For each strategy I have set for myself, I have tried to find the name of a certain role or function which has already existed in social reality". ${ }^{6}$ I would like to stress here that the farther we move away from 1989 towards the present, the less clear and less useful for critical reflection the authorial strategies become - up to the point just before the turn of the millennium - when they become part of the history of Polish cinema.

The post-WWII era of Polish film began with features based on the "witness strategy" principle, characterized at first by the narrator-observer presenting a thesis; or the perspective of the "gentle agitator" or "aggressive agitator," who in fact assumed the role of a "witness-mystifier." After the demise of socialist realism in 1956, Polish cinema developed dynamically, working out multiple authorial strategies. Each year more than 30 feature films and 300 documentary films were made. Despite the oppressive straitjacket of Marxist-Leninist ideology, cinema gained prestige, and for almost 25 years kept a sizeable and faithful audience. Most directors developed authorial strategies such as the strategy of mediator, psychotherapist, loner, historian-interpreter, moralizer and protester. These strategies enabled the filmmakers to communicate with their audiences beyond the official propaganda and political platform of social interaction. Filmmakers were winning the battle against censorship without much difficulty because they "conversed" with their viewers "between the lines," using allusion, subtext and hints, creating metaphors that were split between realism and symbolism, so much so that even today many scenes from these films provoke disputes on whether they refer to specific facts or over their artistic meaning and significance.

The social and artistic significance of such authorial strategies is visible especially in contrast to the official strategies, based on the legitimization of the political power of the Communist party, unpopular with audiences, such as the strategy of teacher, witness-mystifier, historian-mystifier, good servant, collaborator, and historian-agitator. Today, almost nobody watches these films based on the socialist-realist aesthetic conventions, or probably even remembers them. 
A mortal blow for Polish cinema, which had managed to escape from the official discourse, was the introduction of martial law in December 1981, after which the artistic life in Poland became paralysed. One can say that for a number of years, cinema severed its relations with the wider audience. Ambitious films, showing the country suffering from a "profound schizophrenia of adolescence," made during the time immediately preceding martial law, such as Nadzór (Custody, 1983, released 1985), Wolny strzelec (Freelancer, 1985) by Wiesław Saniewski, Przypadek (Blind Chance, 1981, released 1985) by Krzysztof Kieślowski, Kobieta samotna (A Woman Alone, 1981, released 1989) by Agnieszka Holland, Matka Królów (Mother of Kings, 1982, released 1987) by Jerzy Zaorski, Przestuchanie (Interrogation, 1981, released 1989) by Ryszard Bugajski and Ręce do góry (Hands Up!, 1967, new version 1981, released 1986) by Jerzy Skolimowski, were for more than half of decade stopped by censorship, or after 1985 released to limited distribution. The masters of Polish cinema went silent during that time. Andrzej Wajda made merely two films - only one of them in Poland - Kronika wypadków mitosnych, (Chronicle of Love Affairs, 1986), based on the novel of Tadeusz Konwicki. Krzysztof Zanussi made four - but all of them abroad.

Directors who collaborated with the authorities were totally ignored by the audience. Only few films were financially successful, such as the adaptations of historical novels by Stefan Żeromski and Eliza Orzeszkowa, Wierna rzeka (The Faithful River, 1983, released 1987) by Tadeusz Chmielewski and Nad Niemnem (On the Banks of the Niemen, 1986) by Zbigniew Kuźmiński, and four comedies by Juliusz Machulski, Vabank ( Va Banque, 1984), Seksmisja (Sexmission, 1984); Vabank II, czyli riposta (Va Banque II, 1985); Kingsajz (King Size, 1987) which included subtle criticism of totalitarian state and Thais (Thais, 1984) made by Ryszard Ber, a shocking sex costume movie. A minor intellectual stir at the beginning of the decade was caused only by Austeria (The Inn, 1983) made by Jerzy Kawalerowicz, and at its close, by new films directed by Kieślowski - Krótki film o zabijaniu (A Short Film About Killing) and Krótki film o miłości (A Short Film About Love, both released in 1988), followed by the remaining parts of Dekalog (The Decalogue, 1989). Kieślowski has always been appreciated more abroad than in Poland. Only after his premature death in 1996 did he begin to be lionized.

One may say that on the eve of the 1989 political breakthrough, Polish cinema was in danger of extinction, not because of inferior artistic quality but because of lack of audience. Wojciech Marczewski was a director whose generation formed the Cinema of moral anxiety (1976-1981) and who, out of protest against government repression, retreated into self-imposed silence in the 1980s. After the fall of the communist regime, at the congress of the Polish Filmmakers Society (Stowarzyszenie Filmowców Polskich) which took place in Gdynia in 1990, Marczewski asked his colleagues: "Have you really had to make all these films?" The answer was prolonged silence. The one filmmaker who could break the shameful silence was Andrzej Wajda. And he did. He rose and bitterly summarized the past and pronounced a sad prognosis on the future of Polish cinema. In his opinion, the previous decade was an expensive bill to be paid for a long time to come. In 1995 - six years after the political system change - Wajda stated that "the martial law was the biggest disaster that had happened in Poland. All contemporary divisions, all of what is chaotic in our politics and in our art, is the consequence of the martial law. During that time Poland fell apart and it still cannot be consolidated. For me these were wasted years. Everything I did after Danton (made in France in 1983), I consider as films of lost possibilities. [...] I have lost that time the talent to communicate with the audience."7

The truth is that Polish filmmakers were completely unprepared for the change of political system. When state patronage and censorship disappeared, the audience that favoured commercial styles began to dominate, and the directors had to quickly find new producers, new ways of production, artistic formulas and poetics. The cinema freed from political oppression found itself under strong pressure of the free market. From that moment, it leaned to and preferred conventional stylistic devices and standards, styles and fashionable currents clearly showing new authorial strategies.

There are at least four events that document the strangeness and drama of the period around 1989 in Polish cinema. The first was connected with the release - just after the political breakthrough - of films showing the country in the times of the martial law, those made during 1983-86 and in the "last days of the People's Republic of Poland": films as Stan strachu (State of Fear, 1989) by Andrzej Kijowski, Stan wewnętrzny (Inner State, 1983, released 1989) by Krzysztof Tchórzewski, Ostatni prom (The Last Ferry, 1989) by Waldemar Krzystek, Ostatni dzwonek (The Last Schoolbell, 1989) by Magdalena Eazarkiewicz, Chce mi się wyć (I Want to Scream, 1989) by Jacek Skalski and the multiple award-winner 300 mil do nieba (300 Miles to Heaven, 
1989) by Maciej Dejczer, the story of the escape to Sweden of a small group of fifteen-year-old boys. In these films, the "witness strategy" (which was very critical towards the socialist Polish past) dominated but they were found to be of little interest by the audience.

The next event, an unpleasant surprise among filmmakers, was the extremely cold reception in Poland of Tadeusz Konwicki's film Opowieść o Dziadach Adama Mickiewicza - Lawa (Forefathers). The director began to shoot this adaptation in 1988; its premiere was the day before All Souls Day, l November 1989 in Wilno. Not long after that, it was screened at the International film festival in Moscow, in a cinema some hundred metres from the Kremlin walls. But Konwicki's joy was quickly overshadowed following the cool reception of the film by the Polish audience. Konwicki's repeated declarations that he was part of the "parade of victims of romanticism" was further confirmed through his adaptation of that masterpiece of Polish romanticism, nicknamed "Polish idiom." Using the "wise accountant" strategy, he made an original film account of the romantic tradition which for a hundred fifty years had greatly influenced Polish consciousness and national identity. He expressed through his work the conviction that it is not possible to submit uncritically to the formal authority of a romantic text, while disregarding the ambiguities stemming from direct contact with contemporary reality. The film pointed out the weakened viability of the romantic ideology in the consciousness of Polish society. It was this perspective that also caused the film to fail. The director apparently came to terms with this failure because he had finished his long and extraordinary career in film ${ }^{8}$ From that moment on, Konwicki has concentrated all his creative energy on literature.

Another characteristic feature of contemporary Polish cinema was an artistic, and to some extent, commercial success of Ucieczka z kina 'Wolnośc' (Escape from the 'Liberty' Cinema, 1990), by Wojciech Marczewski, who used the "wise accountant"strategy. In it, the filmmaker contemplates the freedom brought to Polish cinema by the free market economy. The subject of this movie are dilemmas which he and his colleagues are now facing. He reminds them and himself of the necessity to put the past behind them and avoid making compromises with their conscience in future creative work. The ups and downs experienced by the film's protagonists illustrate the idea that the gift of freedom to those formerly held captive by ideology often triggers the so-called censor complex and the desire to "escape from freedom." The issue pointed by Marczewski came into one's own in creative practice: at that time Polish cinema needed a real psychotherapy but it could not master it, as it was suffering from ideological compromise.

The fourth important factor was the detachment of the late films by Krzysztof Kieślowski outside the mainstream of Polish cinema. His Podwójne życie Weroniki (The Double Life of Veronique, 1991) and Trzy kolory: Biaty, Niebieski, Czerwony (Three Colours: White, Blue, Red, 1993/94, both in French-Polish production), were honoured all over the world but in Poland they were appreciated - as mentioned previously - only after the death of the filmmaker who developed and used the strategy of the "sceptic observer." The great Polish philosopher, priest and professor Józef Tischner commented on that role succinctly in the homily read at the grave of director: "It is said that Poland didn't understand Krzysztof Kieślowski but what does it mean, Poland? He was not understood by politicians because he was too little of a politician himself. He was not understood by doctrinaires because he was not at all a doctrinaire himself."

The above-mentioned factors created a significant context for Polish cinema in the last decade of the twentieth century. It reacted to the situation in four ways: "First, by producing films referring to the previous epoch and because of that, referring to romantic paradigms which used to be the basis for Polish cinematography before 1989; second, by the outbreak of gangster films; third, by focusing on "provincial" cinema; fourth, by trying to come to terms with the everyday reality of the country in difficult times of political transformation." 9 In other words, the syndrome of freedom simultaneously limited Polish cinema while bringing new, fresh creative energy. Still, the majority of viewers and critics probably agree with Andrzej Werner's opinion on this subject: "Polish cinema - although censored and controlled by the national producer was still privileged by the fact of captivity. [...] It had not to worry about its existence. Functioning outside the market forces, it was not subjected to the dictatorship of mass audience. Moreover, it had ensured a secret agreement with the vast part of the audience. It was the agreement of a captive who does not agree with his captivity and is decided to fight it, even with the help of art cinema. This common language has suddenly disappeared. Disappeared as well the clear aim of cinema and its determined addressee. This concerns not only the cinema. The whole Polish culture has found itself outside the sphere of symbolic language, formed already in the first half of $19^{\text {th }}$ century by the fact of national captivity. [...] And this will probably continue. The dreams about 
cinematography and literature as wise mirrors of social life are probably to be hidden - at least for some time - in a cultural attic. The same applies to the dreams about the whole, organic character of cinema, where artists converse about the society, culture and art with the audience and among themselves. This will be rather an "insular" cinematography." 10

The masters of Polish cinema have fine-tuned their "psychotherapists' strategies" and have stubbornly continued their dialogue with the past, mainly in two modes: one, as before - in a serious and old-fashioned manner, and second, distanced but with a sense of humour. The serious tone was used by the famous Andrzej Wajda. In 1992 he made Pierścionek z ortem w koronie (The Ring with a Crowned Eagle) a polemic with his own Popiót I diament (Ashes and Diamonds, 1958). He showed the dilemma of a young soldier of The Home Army (AK - Armia Krajowa) in the first days after the Second World War. The hero had to decide how he should behave, faced with a new power which was not a Polish one, brought to the country on foreign tanks. Wajda's argument with himself lost artistically because he concentrated too much on the Polish suffering complex and patriotism and too little on the personal dilemma of the hero. He understood his mistake very quickly when he confessed to the press: "this was a frontal collision. Catastrophe!" But he returned to this path two years later with Wielki Tydzien (Holy Week), which was the complement of his own Samson from 1962. In this film he told the story of a Jewish girl whose ex-lover wants to save her from death at the hands of Nazi soldiers. Like his earlier Korczak (1990), this film did not stir up much interest or discussion.

In the New Reality (after 1989), Wajda found himself at the most dramatic crossroads in his creative life which he expressed in an astonishing press statement. He announced he was going to make an adaptation of either the romantic epic Pan Tadeusz, czyli ostatni zajazd na Litwie (Pan Tadeusz: The Last Foray in Lithuania) by Adam Mickiewicz (1834), or the contemporary novel Panna Nikt (Miss Nobody) by Tomasz Tryzna (1994) targeted at teenagers. In fact, he has realized both films, which can be regarded as a sign of determination in search of an exit from a creativity crisis.

First he made Panna Nikt (Miss Nobody, 1996), a story of an adolescent girl living in a block of flats and experiencing the typical problems of children from poor families. The heroine comes to experience despair and existential emptiness and searches for help in the artificial, imaginative world. Panna Nikt did not become a teenage blockbuster - on the contrary - it was clearly incompatible with young audiences' interests. However, Pan Tadeusz (Pan Tadeusz: The Last Foray in Lithuania, 1999) was seen in the first three weeks after its premiere by almost 20 percent of Poles. The film nostalgically refers to tradition, to "thinking through romanticism" and amply expresses the spirit and beauty of poetry. It was enhanced by the performances of prominent actors and a rare beauty of images and music composed by Wojciech Kilar. But - everybody was sure about it - it was nothing more than a perfect illustration of its literary model.

Attendance loss and artistic failure were the experience of all the other "serious" interpreters of history Filip Bajon, creator of the film Poznan 1956 (Poznań 56, 1996) and Przedwiośnie (The Spring to Come, 2001), based on the novel by S. Żeromski, which showed the dramatic beginnings of the Polish state after the end of the First World War; Jerzy Zaorski, author of the film Panny I wdowy (Maidens and Widows, 1991) and Robert Gliński, director of the drama Wszystko, co najważniejsze (All That Really Matters, 1992). Just slightly better was the critics' and audiences' reception of ambitious war morality plays made by young director Leszek Wosiewicz, depicting the reality of Nazi camps (Kornblumenblau, 1989) and Soviet ones (Cynga, 1992) as well as an adaptation of the bitter-filled prose by Tadeusz Borowski about a Ghetto escapee, Pożegnanie z Maria (Farewell to Maria, 1993), filmed by Filip Zylber.

Only those directors who bade farewell to legends and romantic myths or attempts to create an allencompassing vision of history or to film stories that were taboo during the communist censorship, succeeded in the second half of the decade. The closest to the spirit of the new epoch seemed to be the approaches and poetics based on grotesque paradoxes, the absurdities of a Sławomir Mrożek or Witold Gombrowicz and on mocking and twisting the past. Also popular were the bitter comedies Zawrócony (Reverted, 1994) and Putkownik Kwiatkowski (Colonel Kwiatkowski, 1995) by Kazimierz Kutz as well as Cwat (At Full Gallop, 1996) by Krzysztof Zanussi. After completing the historical drama Śmierć jak kromka chleba (Death as a Slice of Bread, 1994), a serious reconstruction of tragic events which took place at a Silesian coal mine during the first days of martial law, Kutz, who liked to use the "strategy of psychotherapist," gained viewers' sympathy for films that showed the ambiguity of the Polish character and 
their split identity. Professor Zanussi, up to this moment always serious, provoked audiences to a deeper reflection on the sinister reality of Stalinist times through his humorous story about his aunt, who, through her love of horses and horse riding, was quite successful in her struggle against communism and its gloomy existence.

Zanussi also made historical movies and three contemporary dramas on moral and metaphysical issues, which were awarded at numerous Polish and international festivals. In Dotknięcie ręki (The Touch, 1992, PolishEnglish production) he told the story of the meeting of two men - an old English composer experiencing a crisis in his creativity and loss of belief, and a young musicologist from Cracow -symbolizing the meeting of two cultures, two systems of values, personalities and different sensitivities connected to art and life. In this film Zanussi asked some interesting questions on the existence of good and evil, on creative activity and on the possibility of reaching the absolute or God through music. However, more interest and appreciation met his other film, Życie jako śmiertelna choroba przenoszona droga ptciowa (Life As a Fatal Sexually Transmitted Disease, 2000), a treatise on existential, thanatological and eschatological subjects. His hero was an atheist, the mortally ill doctor, Tomasz, who was searching a way of reconciliation with Eternity. In 2002, Zanussi used an atypical artistic procedure, by making Suplement (The Supplement), a film which was a kind of appendix to Życie, jako śmiertelna choroba.... Zanussi referred to heroes and events known to the audience from the previous film and even quoted some fragments, foregrounding episodic characters from the earlier film.

It should be stressed here that the "psychotherapist" directors did not manage to create a real dialogue with the audience. Moreover, films such as Pierścionek $z$ orlem w koronie (The Ring with a Crowned Eagle) and Smierć jak kromka chleba (Death as a Slice of Bread) were the biggest financial failures in the decade. The "strategy of the psychotherapist" became completely useless in the context of film communication developing under the pressure of the free market. ${ }^{11}$

Films de-falsifying the socialist reality were often very attractive in narrative and visual aspects but they were not easily received. For example, Gry uliczne by Krzysztof Krauze (Street Games, 1995), about the Workers' Defence Committee (KOR - Komitet Obrony Robotników), "Solidarity" and the political murder of a student (Pyjas), showed a young journalist's investigation but the story was lost in a postmodern game of styles, narrative forms and audiovisual techniques.

In the wave of de-falsification films, filmmakers often became interested in the issues of Polish-Jewish relations, Jewish culture and the topic of religion and metaphysics which used to be controlled by censorship. Polish critics appreciated the courage of Jan Łomnicki's Jeszcze tylko ten las (Just Beyond That Forest, 1991) which grappled with the problem of "folk anti-semitism". The director tried to breach stereotypes connected with it. His film's heroine was a washerwoman who was paid to take the teenage daughter of her Jewish employer out of the ghetto to hide her in the countryside. Despite her dislike for Jews, she agreed to be shot together with the girl. In the above-mentioned Wielki Tydzien (Holy Week, 1994), Wajda did not avoid a formulaic plot or moralizing. But the drama Daleko od okna (Keep Away from the Window, 2000) by Kolski, based on Hanna Krall's reportage about a family hiding a young Jewish girl in a wardrobe, was simply lacking psychological depth and emotionally and intellectually moving tension. The best films on this issue were realized by Polish directors living abroad - Yurek Bogayevicz and Roman Polański. In Boże skrawki (Edges of the Lord, 2001, Poland-USA), with Willem Dafoe playing the main character, Bogayevicz convincingly shows the Polish countryside during the Holocaust, the variety of people's reactions to the evil surrounding them, but manages to avoid unambiguous condemnation, accusation and moralizing. Polański in his Pianista (The Pianist, 2002, Poland-France) presents the real and incredible history of Władysław Szpilman, a Polish Jew who managed to escape death several times due to his musical talent. The tragic fate of a lucky man was turned in this film into a universal myth presenting both the absurdity of the Holocaust and the absurdity of salvation.

A visible sign of radical change in Polish production after 1989 was the quick marginalization of historical accounts by commercial cinema and the appearance of satires on earlier masterpieces of Polish cinema. In Człowiek z... (Man of..., 1993), Konrad Szołajski spoofed Wajda's celebrated Człowiek z marmuru (Man of Marble, 1976) and Człowiek z żelaza (Man of Iron, 1981) in a local version of Monty Python. And in the comedy Operacja "Koza" (Operation "Goat", 2000), the story of which begins at the point where the story 
of Cztowiek z...ends, Szołajski extended his reference range both to the earlier and the contemporary periods. The film was a pastiche and parody of both the political and erotic cinema, ridiculing the Polish propensity to turn everything into myths and legends. In a similar tone - with the same irreverence and superficiality Rafał Wieczyński led a polemic with Kieślowski in his grotesque Naprawdę krótki film o miłości, zabijaniu I jeszcze jednym przykazaniu (Really Short Film..., 1992). He limited himself to showing only the comic side of tragedy, minimizing the spiritual dimension of the protagonists. Another satire came from Piotr Szulkin. In Mięso (Meat, 1993), he laughed at national history (the film's subtitle Ironica refers to Eroika (Eroica, 1957, Andrzej Munk), using a cutlet as the national flag.

The model for popular cinema became the gangster film, which reached its apogee in 1992-93. The creator of this trend was Władysław Pasikowski who, in his film debut Kroll (1991) and later in Psy (Dogs, aka Pigs 1992) and Psy 2 (Dogs 2 / Pigs 2, 1994), depreciated the traditional ethos of the intelligentsia, substituting intellectual idealism for cynicism, underestimating accepted values, promoting male chauvinism and the cult of money, materialism, sensationalism, violence and sex. The strategies of "anti-intellectual cynics" were adopted by a dozen or so other directors, representing not only the youngest generation, but also those of middle age. This cinema model was appreciated by television as well - the success of the three-part TV-series Ekstradycja (Extradition) by Jerzy Wójcik was proof of that. Such movies attracted audiences not only by their "American" style, but especially by their provocative stance towards the Polish past and the use of colloquial dialogues. Thematically and stylistically, they corresponded with the everyday life of the viewers. The forty-year-old actors, former idols of youth such as Bogusław Linda, Marek Kondrat and Cezary Pazura, still popular in their middle age, mocked on screen the ideals of the Solidarity movement which had triggered the Polish "revolution," laughed at slogans and formulated phrases that quickly became colloquial idioms "Because she bad woman was," "We Pigs need to stay together" or "What do You know about killing?"

Similarly certain socially critical films, such as Śmierć dziecioroba (Death of a Childmaker, 1991) by Wojciech Nowak, depicted an all-embracing ugliness of the human environment, a world totally degenerated and the protagonist motivated only by cynicism. Prostytutki (Prostitutes, 1997) by Eugeniusz Priwieziencew, Gniew (Anger, 1997) by Marcin Ziębiński, portrayed extreme brutality, the heroes behaving as if they were programmed to aggression; in Billboard (1998), director Łukasz Zadrzyński treated the audience as psychopaths or lovers of sadistic phantasy. Moreover, independent cinema developed various ties with the gangster film. For example, Piotr Krzywiec in his brutal Czerwona rewolucja (Red Revolution, 1999), based on Quentin Tarantino's and Pasikowski's movies, expressed his "dissatisfaction with the comeback of bolshevism to Poland."

The mid-90s brought a new variant of the gangster movie. It was represented by films such as Mlode wilki (Young Wolves, aka Smugglers, 1995) and Młode wilki 1/2 (Young Wolves 1/2, aka Smugglers 1/2, 1998) by Jarosław Żamojda. Wolves (smugglers) were of course "brothers" of dogs (pigs) and a metaphor of adolescence. Żamojda showed in his film a group of high school students who wanted to get rich quickly, which was possible only by becoming gangsters and smugglers, and going down the road of crime. The amorphous structure and form of Młode wilki 1/2 proved that neither logic nor message was important in this kind of film. This kitschy film, whose only virtue was the music of the pop group "Myslovitz," was seen by more viewers than Młode wilki. This style of gangster film proved to be short-lived. "Young wolves" quickly became "older wolves," earning money on the stock exchange and experiencing conflicts with the mafia (Pierwszy milion / The First Million, 2000, by Waldemar Dziki), playing the role of salesmen seeking to be promoted in the hierarchy of modern companies (Nie ma zmituj / No Mercy, 2000, by W. Krzystek) or just simply having romantic dreams ( 6 dni strusia, / 6 Days of Ostrich, 2001, by J. Żamojda).

An interesting twist to the gangster film was given by Juliusz Machulski who, already in his parody on the adventures of an American gangster of Polish parentage in Russia, Déjà vu (1989), was close to the later stories and genre ideas of Pasikowski. Machulski in Girl Guide (1995) combined this trend with a postmodern play with randomly chosen formulas of action cinema. Machulski's Kiler (Killer, 1997), a comedy in which the place of the super-hero was taken by a clever taxi driver, was the acknowledged epitaph of the gangster film. The protagonist of this film was so much loved by Polish and foreign viewers that he returned to screen in the sequel Kiler-ów 2-óch (2 Killers, 1999), a comedy disguised by the conventions of the action genre.

This dynamically developing model of popular cinema, which defeated other trends and tendencies, quickly 
became depleted. Already in 1996 there appeared only parodies of the gangster genre. Such pastiche films as Kiler or Sara by Maciej Ślesicki definitively closed this chapter in the history of new Polish cinema. After 1997, there arrived a second wave of this trend, - of less consequence in both form and content - created by such directors as Jarosław Żamojda and Paweł Wereśniak, author of the morally ambiguous melodrama Zakochani (Lovers, 1999).

While characterizing the Polish gangster film, it is worth mentioning a certain phenomenon in Polish cinema after 1989. This period introduced 49 directors; two cinematographers - J. Wójcik, (one of the originators of "Polish school") and J. Żamojda; five actors - Bogusław Linda, Krystyna Janda, Eugeniusz Priwieziencew, Olaf Lubaszenko and Marek Kondrat; and 42 graduates of film schools who had earlier completed a short, documentary, serial, commercial or video clip. Since the beginning of 1990s, three debuts determined three tendencies in Polish cinema: the above-mentioned Kroll introduced the gangster film; Pożegnanie jesieni (Farewell to Autumn, 1990) by Mariusz Treliński can be defined as the first postmodern Polish film that captivates with its visual opulence and profound interpretation of literary material and its use of the grotesque and ironic humour.

I fully agree with Tadeusz Lubelski, who in 1994, summarized the output of this five-year period with the following words:

"The key of the majority of debuts is rather gloomy and hopeless; it reflects the depression caused by the lack of perspectives, felt by the maturing generation. These films, mostly concerning contemporary provincial Poland, show a world which is ugly, degenerated and valueless. So it is in the tragicomedy Śmierć dziecioroba (Death of a Childmaker, 1991) by Wojciech Nowak, in Dorota Kędzierzawska's poetical work, Diabty, Diabty (The Devils, the Devils, 1991), in the apocalyptical Czarne stońca (Black Suns, 1992) by Jerzy Zalewski, in the grotesque Naprawde krótkim filmie o miłości, zabijaniu I jeszcze jednym przykazaniu (Really Short Film..., 1992) by Rafał Wieczyński, [...]. Despite of this gloom, the authors work out their own expressions, search for their own attitudes and in their own way fight with this degenerated world. The whole of Polish cinema is searching for its own expression. It is still alive, although it is now not so vivid, intense and all-embracing as it used to be in previous epochs. In fact, its past intensity is frequently mentioned today as a reference point - in citations and polemics with tradition in contemporary cinema. This still vivid tradition can be treated as a good prognostic sign." ${ }^{12}$

However, the practice of filmmaking disproved the last thesis of Lubelski, since through a third debutant (apart from Pasikowski and Treliński) emerged a true art film, which removed itself from the past. Astonishingly, the director did not at all stress its connections with the reality of the 90s but created a magical world of the Polish province.

This debutant was Jan Jakub Kolski, who worked out an original strategy of "storyteller." He shot a series of films, concentrating - and this is unique not only in Polish film history but in its contemporary art cinema - on the countryside, villages, small towns and provinces, omitting completely big history. He was interested in history with a human face, or even the "trash heap of history." Captivating arcadias on film had already been made by precursors of this trend, such as Andrzej Barański (Kramarz / The Peddler, 1990 and Nad rzeka której nie ma / By the River Nowhere, 1991), Andrzej Kondratiuk (Wrzeciono czasu / The Spindle of Time, 1995 and Stoneczny zegar / Sundial, 1997). Kolski, who released a new feature almost every year, earned the appreciation of audience and critics, both Polish and foreign. All his films, especially Cudowne miejsce (Miraculous Place), Jańcio Wodnik (Johnnie Water-sprite) and Historia kina w Popielawach (History of Cinema in Popielawy) are fascinating due to the mythologization of reality and formal stylization. On the ethnographic level, human warmth and interest in provincial life dominates. On the narrative level are reflections on the lasting and passing delights and bitterness of the simple life and peripheral forms of folk religion (specific kinds of paganism, the occult); on the stylistic level prevail pastel tones, shots full of light, wide-angle perspectives, panoramas depicting the space between Heaven and Earth as a reflection of the space between man and God. Certainly, Kolski has created the most original approach in Polish cinema of the 1990s.

By the turn of the millennium, new Polish cinema had depleted all their new formulas. Today it seeks - a positive sign - ways of understanding the present, but also looks for salvation in huge productions, especially 
adaptations of popular literary works. The biggest blockbusters in recent years have been adaptations of Ogniem I mieczem (With Fire and Sword, 1999) by Jerzy Hoffman (over 7m admissions, production cost 25m złoty, box-office 104m złoty), Pan Tadeusz (Pan Tadeusz: The Last Foray in Lithuania, 1999) by A. Wajda (over $4 \mathrm{~m}$ adm/ 13m / 81m zl), Quo vadis? (2001) by Jerzy Kawalerowicz $(2.2 \mathrm{~m}$ adm / $63.5 \mathrm{~m} / 68.5 \mathrm{~m}$ zł), W pustyni I w puszczy (In Desert and Wilderness, 2001) by Gavin Hood (2.2 m adm / 17m / 25m zł) and Przedwiośnie (The Spring to Come, 2001) by Filip Bajon (1.7m adm / 21m / 21.3m zł). Box-office successes of these films are mostly the result of school group excursions and not proof of a revitalizing trend in Polish cinema. Paradoxically, authors of these movies used the unambitious "strategy of illustrator" and thus minimized the risk of failure. Megalomania certainly will not become a characteristic of new Polish cinema, if only because the repertoire of literary masterpieces waiting to be adapted is practically depleted.

Polish feature film did not have much success with chronicling, observing and interpreting political, economic and cultural changes in the country after 1989. Although it has not omitted these issues, films in which such issues dominated, apart from a few exceptions, were mostly of little importance, "literary" discourses or incoherent constructs. This was not surprising: it was hard to comprehend the scale and nature of all the changes, to understand and evaluate them properly and predict consequences. The transformation of the political system coincided with globalization and a wider use of media and new technologies. Poland was then in the situation described by Tomasz Szkudlarek while reflecting on the condition of national identity:

"We have gained freedom, but we do not know who and where we are. We are between liberalism and democracy, which are both constructed from borrowed western icons and longing for one's own authenticity, uniqueness and cultural purity.[...] While integrating with liberal Europe, more and more we are afraid of the Others. [...] At the same time we are becoming more xenophobic as well as more tolerant; approaching the utopia of a multicultural open society, we are becoming more distant to it. The territory of cultural indetermination becomes bigger and bigger. [...] It is more and more necessary to complete it by ideologies which could give it some acceptable sense. Indeed, it is a very dangerous, a very significant time." 13 The drama expressed in these words is reflected in the creative striving of Polish film directors, even today.

The drama expressed in these words is reflected in the creative striving of Polish film directors, even today.

Up to the mid-1990s, the extraordinary inventiveness in deciphering Polish identity was expressed by Bolesław Pawica and Grzegorz Królikiewicz. In Tramwajada (The Tram Odyssey, 1990), Pawica depicted a group of young people who stole a tram to spend New Year's Eve night on it. The tram was obviously a metaphor of escape. Królikiewicz also made an extraordinary and evocative psychodrama Przypadek Pekosinskiego (Case Pekosinski, 1993). Its hero was a real alcoholic, who did not know anything about his roots and who enacted scenes from his own life, linked to ideologies and historical events.

In the second half of the 90s, director Marek Koterski tried to formulate thoughts about Polish identity by creating one of the most controversial, even shocking film styles. Already in his 1989 Porno, by showing "Polish" sex in action, he demonstrated a critical approach to the world around him. He successfully continued the discourse on the same subject in Ajlawiu (I Love You, 1999), a tragicomedy on the erotic obsessions of a middle-aged couple (this time he used only obscenities), and in Dzien świra (The Day of the Freak, 2002), awarded the Grand prix at the Film festival in Gdynia. The satire in the latter film is blatant: the paranoid lonely hero filled with fear and aggression, is the unattractive Adaś Miauczyński, a Polish language and literature teacher and an unsuccessful poet. He lives in a typical block of flats and every morning, looking at his housing estate he says: "What a shit, fuck!" Koterski presents this in such a way that the complexes of the protagonist hit the viewers hard, almost hemming them in.

At the end of the 1990s and at the beginning of the new century, realist trends emerged which both critics and viewers saw as signs of hope for the future, that Polish cinema might achieve a better cultural position and would be able to compete successfully with foreign films. In Dtug (The Debt, 1999), K. Krauze used a psychosociological method of analysis of reality. The film was made as a thriller but it was not sensationalist. The director took the subject straight from life, in the story of two young businessmen who murdered a blackmailer harassing them. The artistic and commercial success of Dlug was the result of the film's powerful effect on viewers as well as its strong metaphorical element. This tendency reappeared in Komornik (Debt Collector, 2005) by Feliks Falk, depicting the cruel reality of rampant Polish capitalism. 
A second tendency began with Cześć Tereska (Hi, Tereska, 2001) by R. Gliński, about a lonely girl living in an apartment block who embarks on a road of crime to escape her frustrating world. The typical heroes of this socially concerned trend were teenagers. The most memorable among them is Owoce mitości (Harvest of Love, 2001) by Marek Żydowicz, whose teenage hero lives in a world completely deprived of feelings and emotions.

Such an "aggressive" approach to reality was characteristic for films of the so-called Generation 2000, including Łukasz Barczyk (Patrze na ciebie Marysiu / I'm Looking at You, Mary, 2001), Grzegorz Lipiec (...że życie ma sens / ... That Life Has Its Sense, 2001), Małgorzata Szumowska (Szczęśliwy człowiek / Happy Man, 2001), Artur Urbański (Bellissima, 2001), Mariusz Front (Portret podwójny / Double Portrait, 2001) and Maciej Pieprzyca (Inferno, 2001). This "new cinema of moral anxiety" was dominated by poverty and frustration, lack of perspective, disillusionment with contemporary Poland and the impossibility of defining Polish identity.

In 2002, the focus of film critics' interest was the off-mainstream Zmruż oczy (Squint Your Eyes) by Andrzej Jakimowski, which looked at the problem of the split personality complex in Polish identity from a new vantage point. The protagonist is a young guard of an abandoned farm in the Polish countryside, a former teacher and an amateur of Greek poetry, who, for unknown reasons radically changed his life by leaving the town.

In the Polish cinema of the past fifteen years, with the exception of the gangster and provincial films, there have been no new movements, schools, waves, trends, or film theories in the traditional sense. It is hard to discuss in such categories the above-mentioned Generation 2000, a TV programme of low-budget films made by new 35- and 40-year-old directors. But it is still possible to distinguish three creative formations, namely women's cinema, film debuts and off-mainstream or independent cinema. They formed, distinctly, the general character and image of the whole Polish cinematography.

The most disappointed with the Polish reality seemed to be the youngest debutants, who portray this in their rather depressing films and conversations with journalists. For example, Ł. Barczyk, in response to the question on the causes of the failure of Polish cinema, answered: "Failure? This is the time in which we live. [...]". Przemysław Wojcieszek, in his opinion on cinema, stated: "It is just a dying branch of pop culture. It is definitely superseded by interactive computer games." ${ }^{14}$ And Barbara Medajska considered that the threats to our film art are located in Poland itself: "The crisis of cinema is the result of a crisis of society, a sign of crisis of the power of the elite [...]". Sławomir Fabicki claimed that: "The French New Wave [1959-1968] cemented the idea of defying the "daddy's cinema." We don't have anybody to defy, we can't refer to anything. Polish cinema doesn't exist." 15

From the reflections so far it follows the approaches and styles closest to the spirit of contemporary times are those based on the grotesque, paradox and mockery, such as those by Witkacy, Gombrowicz and Sławomir Mrożek. Mrożek's dramas have neither become the prototype for feature films nor direct inspiration for filmmakers.

The adaptation of Witkacy's Nienasycenie (Insatiability, 1930), realized by Wiktor Grodecki, did not fulfill any expectations. A meandering plot, the tedious deviations of the protagonists against the background of a decaying Poland at the end of the $19^{\text {th }}$ century, turned out to be only a "cabaret" which did not prove - as Witkacy thought - that man deprived from values, philosophy, art and individuality is condemned to eternal insatiability. This unsuccessful film could have been, however, appreciated by the author of the novel, who detested cinema and thought it to be the symptom of "definite mechanization and idiocy."

Already in 1992 Ferdydurke (30 Door Key, UK-Poland), the first novel (1937) by emigré writer Witold Gombrowicz, became the subject of interest of Jerzy Skolimowski, a director forced to emigrate in 1968. One of the greatest individuals of Polish cinema of the 1960s, he acted in his own films constructed from loosely connected episodes, the role of an outsider who does not accept the "socialist" reality and who seeks his own way of life (Rysopis / Identification Marks: None, 1964; Walkower / Walkover, 1965; Bariera / Barrier, 1966). By adapting Ferdydurke, Skolimowski made a film showing not the deformed reality of the original, but an unnatural, empty world of affectations. Viewers were offered small satisfaction from the Gombrowicz-like perverse irony, expressed in the words: "And who saw it - is a ninny!" 
Neither did J. J. Kolski succeed in making a faithful adaptation of Pornografia (Pornography, 1960), a blasphemous novel in respect to Polish sanctities - the Nazi occupation, The Home Army and Christian moral norms. Despite this, however, he managed to make - as proved by almost all reviews - a good film. The inaccurate title of the film refers to the erotic undertone of the novel, rather than the film version, in which the director touches on the issues of fear, lawlessness, violence, responsibility and the impossibility of isolation from one's surroundings. However, this work does not measure up to Kolski's other films. Similarly, it does not reach the deep layers of Polishness, hidden in the depths of Gombrowicz's imagination.

An even worse interpretation of contemporary Polish reality was Piotr Szulkin's Król Ubu, an adaptation of Ubu the King by Alfred Jarry. Written in 1888 by a fifteen-year-old boy about a common and stupid tyrant, set in an imaginary Poland, the film was turned into a satire about the abominable masses which form both the governing and the governed. The director has not moved beyond simple, playful metaphor and, as one critic wrote: "Ubu AD 2004 gives the impression of a film made by somebody who has lost contact with the audience. In prophetic tone he tells us things that we already know. He polishes the same paths which were used by dozens of 'cabaret-makers' before him." 16

The issue of weakness of Polish cinema was addressed by directors in their film works. They characterized the situation in which Polish cinema found itself by epithets such as: "pretentiousness," "lack of talent," "chaos," "pursuit of money" and "stupidity." This was illustrated by two films: Superprodukcja (Super-production, 2003) by J. Machulski and Polisz kicz projekt (Polish Kitsch Project, 2002) by Mariusz Pujszo. The first production, with Polish film stars, was dominated by marvellous computer effects. The second was a comedy, with references to the independent American film Blair Witch Project (1997) showing the social environment of independent cinema. The hero of Polisz kicz projekt is making a "home movie" and his only aim is to make a consciously bad film, stating that it is "a contemporary version of The Cruise (Rejs by Piwowski in 1970)." Pujszo himself played the role of a casting director which has been the source of his income and the process of filmmaking is shown to be a very boring activity.

The discussion on the weakness of Polish cinema was summarized by film critic Tadeusz Sobolewski: "We are poor provincials on tour. Deprived of visions, anxious about our fate, we look on ourselves distrustfully and guard our bundles with fear that somebody will steal them. Provincialism of our cinematography is not caused by lack of talent but by the fact that we are in a situation of endless "quick fixes" where conditions are dictated by distributors and the owners of multiplexes. The only chance is integration with European cinema. We are very close to it." ${ }^{\prime 7}$ That chance, according to critics, is the resolution on cinematography which was accepted in 2005 by the Polish parliament. Based on the pattern of European solutions, it proposes the broadening of the sources of film financing, so that a part of it will be taken from income from cinema tickets, the sale of video cassettes and DVDs, and the participation of television production according to European Union norms. There are also plans to sell media space which up to now, unlike in Europe, was offered for free. The resolution will of course not solve all the important problems facing Polish cinema.

In 2008, four years after Polish accession to the European Union, in the period when globalizing processes and multimedia expansion are intensifying, Polish cinema has neither formed its identity and originality nor defined its traditional one. Therefore, it is not a cinema that could rise to the expectations and aspirations of Poles who would like to be active participants of a global community enriched by local cultures.

[Translated by Anna Maj]

\section{Notes}

1. K. Kieślowski: Wolności nie ma (Freedom does not Exist), Kino 1992, No 8, 11.

2. T. Miczka: "Cinema Under Political Pressure: A Brief Outline of Authorial Roles in Polish Post-War Feature Film, 1945-1995", Kinema (Waterloo), Fall 1995, No 4, 32-48; changed versions of the text: "Kino pod nátlakem politiky. Stručný přehled historie hraného filmu v poválečném Polsku, 1945-1995", [In:] A. Wajda: Moje filmy, Votobia, Olomouc 1996, p. 201-226; "Filmot pod presija na politikata. Kratka skiza za istoriatot na igraniot film vo povojena Polska, 1945-1995," Kulturen Život (Skopje) 1996, No. 34, 28-38 
and "El cine bajo presión política: Polonia, 1945-1989", Comunicación y Sociedad (Pamplona) 1998, No. 2, $105-121$.

3. Historiographer of Polish cinema M. Hendrykowski in his book: Autor jako problem poetyki filmu, Poznań 1988 distinguishes, in various periods of film history, around twenty roles such as witness, prestidigitator, clown, fabulator and mythicist.

4. Theorist and historian of literature, E. Balcerzan, represents such approach in his book: Poezja polska $w$ latach 1939-65. Część I. Strategie liryczne, Warszawa 1984.

5. T. Lubelski, "Strategie autorskie w filmie polskim," Literatura 1985, No. 12, 52.

6. Ibid. The author uses this method also in his book: Strategie autorskie w polskim filmie fabularnym lat 1945-1961, Kraków 1992 and 2000.

7. A. Wajda: "Albo Pana Tadeusza albo Panne Nikt," Kino 1995, No 2, 9.

8. Film poetics and the reasons of its reception failure are the subject of my analysis: Wielka improwizacja filmowa - Opowieść o Dziadach Adama Mickiewicza - Lawa Tadeusza Konwickiego, Kielce 1992 , pp. 32.

9. M. Przylipiak, J. Szyłak: Kino najnowsze, Kraków 1999, p. 172.

10. A. Werner: To jest kino, Warszawa 1999, pp.152-153 and 159. I discussed the "insular" character of Polish cinema in my work "Epitafia, emfazy, enigmay, ewenementy i epizody. Polski film fabularny po 1989 roku," Postscriptum 2003, No 12, 655.

11. The production costs of Pierścionek z ortem $w$ koronie was 1,5 million zloty while the box-office takings were 29,000 zloty. The making of Śmierć jak kromka chleba cost 1,8 million zloty while the tickets sales amounted to 33,000 zloty.

12. T. Lubelski: "Film fabularny." [In:] Encyklopedia kultury polskiej XX wieku. Film. Kinematografia, ed. E. Zajiček, Warszawa 1994, p. 178.

13. T. Szkudlarek, "Wydarzenie, urzeczywistnienie, różnica: edukacyjna autokreacja społeczeństwa" [In:] Różnica, tó̇samość, edukacja. Szkice z pogranicza, ed. T. Szkudlarek, Kraków 1995, p. 1314.

14. Cit. after I. Cegiełkówna: "Młodzi filmowcy: portret niespójny," Kino 2002, No 2, 7-8.

15. Cit. after M. Kornatowska: "Mówić po swojemu," Kino 2002, No 6, 11 and 13.

16. M. Chaciński: "Ubu Król," Film 2004, No 1, 92.

17. T. Sobolewski: "Prowincjusze w podróży," Gazeta Wyborcza, 15 December 2003, 14.

\section{Author Information}

Tadeusz MICZKA is Director of the Institute of Cultural Studies, Faculty of Philology, University of Silesia, Katowice, Poland. His main fields of research are history of the Polish, Italian, and Central and East European cinemas, film theory, and issues related to modern media, including neo-television, virtual reality, audio-visual communication. Prof. Miczka is the author of many publications on the history and theory of cinema, methodology of education and of comparative researches on contemporary culture. 